\title{
Leadership Behavior in Implementing the Mental Revolution for Improving Teacher Performance
}

\author{
Herinto Sidik Iriansyah', Iswadi²
}

DOI: $10.35445 /$ alishlah.v13i1. 424

Keywords:

Leadership

Principal

Mental Revolution

Teacher Performance
Kata kunci:

Kepemimpinan

Kepala Sekolah

Revolusi Mental

Kinerja Guru
This study aimed to determine the principal's leadership behavior in implementing mental revolution to improve teacher performance at SMK Islam PB Soedirman 2 Jakarta. Research using a qualitative approach with data collection techniques documentation, observation, and interviews. The research subjects were the principal and the teacher. This research shows that the formulation of principal policies in implementing mental revolutions to improve teacher performance at SMK Islam PB Soedirman 2 Jakarta has made written and oral rules according to the vision and mission of the school. It involves teachers, school targets, and school principals in formulating activities to improve teacher skills. These results make teachers better understand the lessons more easily and feel comfortable during school and achieve better quality education. As a leader in implementing a mental revolution to improve teacher performance at SMK Islam PB Soedirman 2 Jakarta, the principal's program is done by good communication. It is not rude, direct supervision, not arrogant and authoritarian, compiling a KKG program, seminars, and the workshop with this program shows encouraging results. Teachers are more disciplined to complete their assignments well. The principal's strategy is to involve all teachers and provide direct examples. The factors that influence the principal's leadership in implementing a mental revolution to improve teacher performance are his desire to improve school performance. This is the main factor that influences it along with other general factors, such as the personal condition of the principal, school organization, the external environment.

\begin{abstract}
Abstrak
Tujuan penelitian ini adalah untuk mengetahui perilaku kepemimpinan kepala sekolah dalam melaksanakan revolusi mental untuk meningkatkan kinerja guru di SMK Islam PB Soedirman 2 Jakarta. Penelitian menggunakan pendekatan kualitatif dengan teknik pengumpulan data dokumentasi, observasi, dan wawancara. Subjek penelitian adalah kepala sekolah dan guru. Hasil penelitian ini menunjukkan bahwa perumusan kebijakan kepala sekolah dalam melaksanakan revolusi mental untuk meningkatkan kinerja guru di SMK Islam PB Soedirman 2 Jakarta telah membuat aturan tertulis dan lisan sesuai visi dan misi sekolah dengan melibatkan guru, sasaran sekolah dan kepala sekolah dalam merumuskan kegiatan-kegiatan untuk meningkatkan keterampilan guru. Hasil ini membuat guru mampu mengajar dengan lebih baik sehingga siswa lebih mudah memahami pelajaran dan dapat merasa nyaman selama bersekolah serta mencapai pendidikan yang lebih berkualitas. Program kepala sekolah sebagai pemimpin dalam melaksanakan revolusi mental untuk meningkatkan kinerja guru di SMK Islam PB Soedirman 2
\end{abstract}

${ }^{1}$ STKIP Kusumanegara, Jakarta

Email: herinto_sidik@stkipkusumanegara.ac.id 2 STKIP Kusumanegara, Jakarta

Email: iswadi@stkipkusumanegara.ac.id 
Jakarta dengan menggunakan komunikasi yang baik (tidak kasar, pengawasan langsung, tidak sombong dan otoriter), menyusun program KKG, seminar dan workshop dengan ini program menunjukkan hasil yang menggembirakan, guru lebih disiplin sehingga dapat menyelesaikan tugasnya dengan baik. Strategi kepala sekolah sebagai pemimpin dalam melaksanakan revolusi mental untuk meningkatkan kinerja guru adalah dengan melibatkan semua guru dan memberikan contoh langsung. Faktor yang mempengaruhi kepemimpinan kepala sekolah dalam melaksanakan revolusi mental untuk meningkatkan kinerja guru adalah keinginannya untuk meningkatkan kinerja sekolah. Faktor utama inilah yang mempengaruhinya bersama dengan faktor umum lainnya, seperti: kondisi pribadi kepala sekolah, organisasi sekolah, lingkungan luar.

\section{INTRODUCTION}

Management in every organization becomes essential to achieve an interest or a goal to be completed. When an organization runs a managerial system well, the organization will live healthily because every element of the organization moves according to the rhythm of the management (Kemal; Suryadi; Rosyidi, 2019). However, it cannot be denied that every organization has limitations in human, financial, and physical resources to achieve organizational goals. Success in achieving goals depends on selecting goals that will be achieved by using resources effectively to achieve these goals. For the organization's goals to be achieved under what is expected, one aspect that should be considered is the human factor and human resource management. The development of human civilization has led to the development of technology directed at advanced technology in recent times and increased human needs and desires in number, variety of types, and levels of quality.

The development of the world of education cannot be separated from the development of the world globally. The rapid advancement of technology and information contributes to education development (Suryadi, et al., 2020). The government is very serious in handling the education sector because with a good education system. It is hoped that future generations of the nation will be qualified and able to adapt to life in facing global competition.

Schools as formal educational institutions aim to shape human personality in developing intellectual students to educate the nation's life. The principal of the school as a leader has a significant role in helping teachers and employees. To improve the quality of education, a principal must improve the performance of his teachers or subordinates. Many factors can affect a person's performance, as a leader and the principal of the school. The principal must provide influences that can cause teachers to be moved to carry out their duties effectively to be better. As an influential leader, he strives to have his teachers follow his advice, suggestions, and necessary orders. Thus he can make changes in the way of thinking, attitude, behaviour that he leads. The advantages it has, namely excess knowledge and experience, helps teachers develop into professional teachers (Iswadi, 2020).

Formal educational institutions are educational institutions that take place in schools in wellorganized management. Besides taking place in the school environment, education can also take place outside the school environment, such as the family and community environment (Story, et al., 2002). This means that education is the school's task (teachers and school principals), but family and society are also responsible for the continuity of education.

The realization of a quality future generation must be started first by providing a good and systematic knowledge, namely through education and teaching by school teachers, including vision and mission, curriculum, the competence of lecturers and staff, infrastructure and facilities, teaching and learning process, supervision. Teachers certainly need to plan, organize, mobilize and supervise properly the preparation of education and teaching that will be given to students. For this reason, school management must function as much as possible in achieving educational programs in schools. Islamic-based school management needs attention. School managers can hope for the successful 
implementation of educational innovation programs if schools do not get good attention from the government, and parents of students will find it difficult to become a superior school (Ratten, et al., 2016).

Schools in the course of their implementation face challenges. Therefore, education managers should be responsive and learn about School Management in applying education as a science and art to carry out its duties. School management is a step that is carried out systematically because it is the lifeblood of achieving school goals to improve student quality and achievement. Therefore, the education process must create global competitiveness, so education managers should make internal improvements to management in an organization, both concerning human resources and its management implementation system.

In implementation of all educational activities at school, the principal asks teachers to carry out the learning process. It include fostering creative abilities, innovative power, problem-solving abilities, critical thinking, and entrepreneurial instincts for students as a product of an education system so that it is expected to be a reference for increasing competence. The principal is as mandated by the Minister of National Education Regulation No. 13/2007. Success or failure of leadership is influenced by the inherent abilities and traits. It is also influenced by the characteristics of the group being led. However, a leader has good leadership characteristics and can carry out group functions. However, success or failure is still determined by situations that affect the school's organizational life (Iswadi and Iriansyah, 2020).

Improving the quality of education on a micro-level is primarily determined by the operationalization of management at the school level. Education is an important issue that must get the attention of all parties. Given the importance of education in improving the standard of living and the smartness of the nation's life, it is appropriate for the government to direct special attention to the quality of education and to expand higher learning opportunities for teachers. The opportunity for further education for teachers aims to improve the quality of education that is faced with the challenges of preparing quality human resources so that they can develop duties and responsibilities for the continuation of national development.

The main role in carrying out the school management pattern lies with the principal and the entire school community, both collectively and individually. The principal is the person responsible for running the school organization. The principal is always faced with the challenge of making changes and developing education in a planned, directed and sustainable manner to improve the quality of graduation. The quality of the principal as a manager is strongly influenced by the managerial capability to empower teachers so that professional teachers who always want to actualize in the form of improving the quality of education are created (Rosdina, Murniati \& Yusrizal, 2015). Leadership is essentially a function of management. The principal must be able to manage his school so that it can develop over time.

The ability to lead by the principal is the essential thing in an elementary school system. Murniati (2008: 133) says that: "leadership is strategic and crucial in the duties and authorities inherent in the position of school principal, the quality of schooling is strongly influenced by the quality of school principal leadership. Quality schools are the demands of stakeholders ".

In educational leadership, leaders must believe that they can work and have the maximum ability and potential to benefit schools. This will happen as long as the leader guarantees the situation and opportunity for creative action.

The preliminary observations are conducted by the researchers from 17 Private Vocational High Schools in East Jakarta. The researchers were interested in choosing SMK Islam PB Soedirman Jakarta as a place of research because, according to researchers, SMK Islam PB Soedirman Jakarta has uniqueness, such as it requires passing a good Al-Qur'an reading test. For prospective teachers and prospective new students, both studying and practising Hajj rituals, and practising janazah prayers. Next is the superiority of PB Soedirman Islamic Vocational High School when compared to 
other private SMKs in East Jakarta, including 1). The portion of Islamic religious education is very large, both academic (6 hours of teaching and learning / 3 subjects), and non-academic (mabit, tahfidh, bina). 'us sholah, manasik, and others); 2) a curriculum that is integrated with Islamic values (Al-Qur'an and Al-Hadith); 3) Quality management (accreditation A, ISO SGS 2015, LSP, and Teaching Factory). In addition, the excellence of PB Soedirman Jakarta Islamic Vocational High School can be seen from the high interest in prospective new students, which increases every year. In 2015 the number of admissions was 113 students. In 2016, there were 168 students; in 2017, it grew to 181 students.

The high interest of students to continue their studies at SMK Islam PB Soedirman Jakarta makes researchers want to know more deeply how school management at PB Soedirman Islamic Vocational School Jakarta plays a role in its implementation management function under the Islamic-based School Management at SMK Unggul. Another factor that makes researchers interested is data on infrastructure to support teaching and learning activities. It includes computer laboratories, industrial work training, learning practice rooms, libraries, wifi, competency test rooms, having a mosque that is quite magnificent, cooperation with the business and industrial world. Cooperation with industries that provide opportunities for students to practice the skills that have been acquired in school.

Currently, SMK Islam PB Soedirman Jakarta academic culture is coloured by Islamic values , which produce not only graduates who have global insight but also graduates who have excelled in the fields of science and entrepreneurship and can accommodate noble morals as a foundation in managing education, so that schools able to produce future leaders who have the strength of high morality.

\section{METHODS}

The method in this research is qualitative by using a case study approach. It is focus on the leadership behaviour of principals in implementing mental revolution to improve teacher performance. The subjects in this study are (1) Principal of SMK Islam PB Soedirman 2 Jakarta (2) Teachers of PB Soedirman 2 Islamic Vocational School Jakarta.

In this research, the approach taken is through a qualitative approach. This means that the data collected is not in numbers, but rather the data comes from interview texts, field notes, personal documents, and other official documents. The goal of qualitative research is to describe the reality behind the phenomenon in-depth detail and thoroughly.

By the focus of research on the leadership behaviour of school principals in implementing mental revolutions to improve teacher performance, the subjects in this study were: (1) Principal of SMK Islam PB Soedirman 2 Jakarta (2) Teachers of SMK Islam PB Soedirman 2 Jakarta. Collecting data is a crucial step in research because the primary purpose of study is to get data.

The data analysis process in this study uses the Miles and Huberman model, where the process starts from data reduction, data display, and conclusion drawing or verification. The data analysis components are as follows:

1. Data Reduction to selecting, focusing, simplifying, separating, and transforming raw data visible in written records in the field. Therefore, data reduction occurs as long as research activities are carried out. Data reduction is carried out before data collection in the field. The data that is reduced in this study are interview data, observation, and documentation. The information that has been collected during the research is then selected for the data needed in this study. This data is called the triangulation technique, which uses various data disclosure techniques to the data source. Testing the credibility of data with triangulation techniques can check data to the same source with different techniques. For example, 70 revealed data on character education in schools using interview techniques, then checked by direct observation in the field to see the character education programmed in schools, then by documentation. This test is carried out so that there is no error in the 
presentation of the data. All parties involved in delivering information on primary data and secondary data are very helpful for researchers in making it easier for researchers to find information about the principal's leadership in building the character of students at SMK Islam PB Soedirman 2 Jakarta.

2. Presentation of data is a structured collection of information that allows concluding and taking action. It show everyday life or social interactions of isolated communities or the learning environment at school. Looking at impressions or displaying data of a phenomenon will help someone understand what happened or did something. Such conditions will assist in conducting further analysis based on the understanding concerned. The most common form of data display in qualitative research is narrative text and events or events in the past. The data presentation is intended to select data according to the needs of researchers regarding the leadership of school principals in building character education for students at SMK Islam PB Soedirman 2 Jakarta.

3. Conclusion/verification was conducted by breadth and depth of field notes, the type of methodology used in data validation and processing, and the researcher's experience in qualitative research. Data reduction, data display, and conclusion/verification must start from the beginning. Withdrawal of this conclusion data is taken in stages, starting with taking a temporary conclusion

Furthermore, data collection techniques can be carried out by observation, interview, questionnaire, documentation, and a combination of the four when viewed in data collection methods or techniques.

\section{FINDINGS AND DISCUSSION}

\section{Formulation of Principal Policies in Implementing Mental Revolution to Improve Teacher Performance}

The priority of the principal of SMK Islam PB Soedirman 2 Jakarta on teachers' ability is to increase the quality of education provided to students from year to year. To achieve this goal, the principal implements policies that have been compiled and implemented regularly. This policy will spark enthusiasm for all teachers to do better things every time to achieve common goals.

The principal is an educator whose function is to guide teachers as his subordinates. For his guidance, the principal can measure teacher performance by seeing students' increased ability such as better grades and student behaviour.

Such policies encourage teachers to do their best in teaching in the classroom and provide direct examples. This means that the principal fully trusts all teachers in all of their commitments. In addition, the principal also communicates directly with students and sees first hand each method used by the teacher for each lesson and their class. This method, by itself, makes everything the teacher does will be known to the principal, which he communicates informal meetings with all teachers. This is what triggers all teachers because students are a form of their evaluation directly and indirectly.

Leadership means the nature, capacity, and ability of a person to lead. The meaning of leadership itself is very broad and varied. According to Charteris-Black, the definition of leadership is "leadership is a process whereby an individual influences a group of individuals to achieve a common goal". Leadership is the nature and values that a leader has.

Many researchers and experts have shared the concept of leadership in various aspects. The division of the essential leadership style and, at the same time, underlying the development of leadership classifications to date is based on the results of research by Lewin (1939). Lewin divides leadership styles into 3 main categories: autocratic leadership, democratic leadership, and delegation leadership. Each of these categories has characteristics and characteristics that distinguish one from another. 
Leader and leadership are like a coin that cannot be separated, in the sense that they can be studied separately, which cannot be separated, in the sense that they can be examined independently but must be seen as a single unit. A leader must have a leadership spirit, and the leadership spirit possessed by a leader cannot be obtained quickly and immediately, but a process that is formed from time to time until it finally crystallizes in a characteristic (Reed, et al., 2011). In the sense that some people have leadership traits but with persistent efforts, they can help establish their leadership attitude.

\section{The Principal Program as a Leader in Implementing a Mental Revolution to Improve Teacher Discipline}

The principal of SMK Islam PB Soedirman 2 Jakarta has programs to improve the discipline of teachers. Smooth mutual communication between the principal and the teachers is the most important among all the programs he implements. The attitude of the principal, namely providing an example of discipline by his actions coupled with the emphasis on official school occasions, has motivated teachers to carry out the discipline as determined and agreed.

The direct and equitable communication that he applies can make all programs run well. For example, in carrying out the program, the principal mentions teachers who attend school and enter their respective classes on time in public. However, he admonishes teachers who are late or late for their class hours separately. This is done to motivate teachers to apply discipline and maintain teachers' feelings and good name who intentionally or unintentionally violate the imposed discipline. The actions make all teachers feel valued, whether they are doing things right or wrong.

Leadership theory developed decades ago, and there have been many references in various forms on this topic resulting from multiple studies. The leadership function in an organization or group is very important because it is the leadership function of an organization to achieve its goals in the right way and way (Plowman, et al., 2007). Understanding the concept of leadership helps individuals and organizations work more effectively and efficiently to achieve the desired goals and conditions. Leadership is an activity to influence people to work together to achieve the desired goals (Ejimabo, 2015).

Currently, the condition of the Indonesian nation is like a large ship in the middle of a vast ocean. This ship is now losing direction and purpose and moving only in circles. All you get is the crashing waves and waves. As a result, all the passengers were drunk and confused. Unfortunately, when the passengers of the layer of millions of people were in a hollow, rusty condition, the engine often broke down. It's just a matter of time. Sooner or later, the big ship will sink, swept away by the ferocious waves and waves. If this continues to be allowed, then get ready for destruction.

Seeing the current condition of Indonesia, we as citizens are obliged to make corrections and improvements immediately. The Indonesian people must complete the ongoing reform process with a mental revolution (Pheneey, 2019). With a mental revolution, we eroded out the negative mentality inherited from the previous order. We eradicate corruption by responding to corrupt people, but we are developing a system and a culture that is not corrupt (Levine, 2005). We must build tolerance and harmony, we get rid of greed, we develop a culture of dialogue to solve problems, we uphold fair laws and build clean judicial institutions, and we close the space for opportunists to move.

\section{The principal's Strategy as a Leader in Implementing a Mental Revolution is to Increase the Responsibility of Teachers}

The strategy used by the principal of SMK Islam PB Soedirman 2 Jakarta is to make rules together with the teacher, then he visits each class to carry out the teacher's task who is unable to do it himself. The principal also evaluates in a meeting with all the teachers how the responsibilities agreed have been carried out. With this strategy, school principals can measure how teachers are responsible, what obstacles arise, and how the solutions are. Direct involvement when making rules will make teachers feel responsible for running it because they made it so that it is not considered an order but carries out the agreement. 
The strategy used by the principal in increasing the sense of responsibility of the teachers is by building good communication. It is carried out with determination and enthusiasm by all teachers. The strategy used by the principal has created a commitment among all teachers that they are a unit so that they will take over the responsibilities of teachers who were absent before being ordered by the principal.

Mental revolution is a rapid change from an ordinary person to a great human being (Sutardi, et al., 2017). To be great, humans must have the courage to make changes. This philosophy can be seen in a caterpillar turning into a butterfly. When he was still a caterpillar, he held it, even tried to get away from it. However, with a beautiful colour shape on his body, people will be happy to look at him when I have enough. Great humans know themselves, know their opponents and master the field (Dweck, 2012). If this can be mastered, humans will automatically have full leadership power.

\section{Factors that influence the principal's leadership in implementing a mental revolution to improve teacher performance}

The factors that influence the principal provide a direct example through his actions on all matters related to improving teacher performance and others, namely the increasing degree of the school he leads. The achievement and good name of the school are big goals to be achieved as the main factors that make him have a strong commitment to increasing the resources of teachers there so that student resources increase which results in goals, achievements, and the good name of the PB Soedirman 2 Islamic Vocational School Jakarta

With these various factors, overall, the principal wants the school students he leads to participate in events and competitions at the provincial and national levels and other high-achieving junior high schools. This desire triggers him to improve all systems there. He realized that the support of all teachers was an important asset for all of his policies, so he treated these teachers as colleagues, not as subordinates. If all the teachers have supported what he has programmed, he will only monitor the process without involving himself more. An award he gives to all teachers to feel that the principal's goals are their own goals, and if those goals are achieved, they are proud too. The teachers realize that their job is not just teaching in the classroom, but also responsible for maintaining a good name and improving school performance.

Seeing the current condition of Indonesia, we as citizens are obliged to make corrections and improvements immediately. The Indonesian people must complete the ongoing reform process with a mental revolution (Ferrazzi, 2000). With a mental revolution, we eroded out the negative mentality inherited from the previous order. We eradicate corruption by responding to corrupt people, but we are developing a system and a not corrupt culture. We must build tolerance and harmony, we get rid of greed, we create a culture of dialogue to solve problems, we uphold fair laws and build clean judicial institutions, and we close the space for opportunists to move (Cameron, et al., 2009).

With a mental revolution, we have made this great nation realize that Indonesia's main capital for achieving progress and just and prosperous society is human beings (Moon, 2009). Our main capital is indeed humans and not natural resources. If Indonesian people have an age mentality that is in tune with the times, Indonesia will become a developed nation and become a role model for the world

\section{CONCLUSION}

The formulation of the principal's policies in improving teachers' abilities at SMK Islam PB Soedirman 2 Jakarta has made written and oral rules according to the vision and mission of the school by involving teachers, school targets, and school principals formulating activities to improve teacher skills such as KKG. In the program, the principal is a leader in improving the discipline of teachers at SMK Islam PB Soedirman 2 Jakarta by using good communication. The principal's strategy as a leader is to increase the responsibility of teachers at SMK Islam PB Soedirman 2 Jakarta by involving all teachers and providing direct examples. The factors that influence the principal's 
leadership in improving teacher performance are the desire to improve school performance to have better understanding at the regional and national levels.

\section{REFERENCES}

Cameron, Lisa; Chaudhuri, Ananish; Erkal, Nisvan; Gangadharan, Lata. 2009. Propensities to Engage in and Punish Corrupt Behavior: Experimental Evidence From Australia, India, Indonesia and Singapore. Journal of Public Economics, 93 (7-8), pp. 843-851. https://doi.org/10.1016/j.jpubeco.2009.03.004

Dweck, Carol S. 2012. Mindsets and Human Nature: Promoting Change in The Middle East, The Schoolyard, The Racial Divide, and Willpower. American Psychological Association, 67 (8), pp. 614-622. https://doi.org/10.1037/a0029783

Ejimabo, Nichodemus Obioma. 2015. The Influence of Decision Making in Organizational Leadership and Management Activities. Entrepreneurship \& Organization Management, 4

(2), pp. 1-13. 10.417/2169-026X.1000138

Ferrazzi, Gabriele. 2000. Using The " $F$ " Word: Federalism in Indonesia's Decentralization Discourse. Publius: The Journal of Federalism, 30 (2), pp. 63-85. https://doi.org/10.1093/oxfordjournals.pubjof.a030085

Iswadi dan Iriansyah, H.S. 2020. The School Management in The Islamic-Based Excellent Vocational High School. International Journal for Educational and Vocational Studies, 2 (10) (2020), 861-870.

Iswadi. 2017. Kepemimpinan dalam Revolusi Mental. Aceh: Natural Aceh.

Kemal, Isthifa; Suryadi; Rosyidi, Unifah. 2019. Management of Lecturer Resource Development at Higher Education. International Journal of Higher Education, 8 (5), pp. 246-256. https://doi.org/10.5430/ijhe.v8n5p246

Levine, David P. 2005. The Corrupt Organization. Human Relation, 58 (6), pp. 723-740. $10.1177 / 0018726705057160$

Lewin, Kurt; Lippitt, Ronald; White, Ralph K. 2010. Patterns of Aggressive Behavior in Experimentally Created 'Social Cimates'. The Journal of Social Psychology, 10 (2), pp. 269299. https://doi.org/10.1080/00224545.1939.9713366

Moon, Suzanne. 2009. Justice, Geography, and Steel: Technology and National Identity in Indonesian Industrialization. The University of Chicago Press Journals, 24 (1), pp. 253-277. $10.1086 / 605978$

Murniati, AR. 2008. Manejemen Strategik Peran Kepala Kepala Sekolah Dalam Pemberdayaan. Bandung: Cita Pustaka Media Perintis.

Pheneey, Christine Edith. 2019. Harnessing Digital Tools in Collaborative Inquiry For Contemporary Interpretation of The Pancasila. The $5^{\text {th }} \mathrm{ACM}$ in Cooperation International Conference in HCI and UX, April 2019, pp. 128-136. https://doi.org/10.1145/3328243.3328259

Plowman, Donde Ashmos; Solansky, Stephanie; Beck, Tammy E.; Baker, LaKami; Kurkani, Mukta; Travis, Deandra Villarreal. 2007. The Role of Leadership in Emergent, Self-Organization. The $\begin{array}{lllll}\text { Leadership } & \text { Quarterly, } & 18 & \text { (4), } & \text { pp. }\end{array}$ https://doi.org/10.1016/j.leaqua.2007.04.004

Ratten, Vanessa; Ramadani, Veland; Dana, Leo-Paul; Rashiti, Shqipie Gerguri. 2016. Islamic Enterpreneurship and Management: Culture, Religion and Society. Entrepreneurship and Management in an Islamic Context, pp. 7-17. https://doi.org/10.1007/978-3-319-39679$\underline{8 \quad 2}$ 
Reed, Lola L; Cohen, Deborah Vidaver; Colwell, Scott R. 2011. A New Scale to Measure Executive Servant Leadership: Development, Analysis, and Impications for Research. Journal of Business Ethics, 101, pp. 415-434. https://doi.org/10.1007/s10551-010-0729-1

Rosdina, Murniati, \& Yusrizal. 2015. Perilaku Kepemimpinan Kepala Sekolah dalam Peningkatan Kinerja Guru pada SD Negeri 2 Lambheu Kabupaten Aceh Besar. Jurnal Administrasi Pendidikan, Vol. 3, No. 2.

Story, Mary; Neumark, Sztainer; French, Simone. 2002. Individual and Environmental Influences on Adolescent Eating Behaviors. Journal of The American Dietetic Association, 102 (3), pp. S40-S51. https://doi.org/10.1016/Sooo2-8223(02)90421-9

Suryadi; Kemal, Isthifa; Setyanto, Eddy; Rachmadtullah, Reza. 2020. Career Development Management of Higher Education Lecturers in Indonesia, A Case Study at STKIP Bina Bangsa Getsempena Banda Aceh. International Journal of Innovation, Creativity and Change, 11 (10), pp. 499-515. https://ijicc.net/index.php/ijicc-editions/2020/163-vol-11-iss-10

Sutardi, Dodo; Haimah; Dihamri. 2017. Mental Revolution Based on Local Wisdom to Improve The Performance of Teacher at School in Remote Are. Proceeding International Seminar of $\begin{array}{lllll}\text { Primary } & \text { Education, } & 1 & \text { (1), } & \text { 66-71. }\end{array}$ http://prosiding.unipma.ac.id/index.php/ISPE/article/view/142

Undang-undang Sistem Pendidikan Nasional, (UU RI No 20 Tahun 2003). 